\title{
Effects of yeast culture supplement on digestion of nutrients and rumen fermentation in cattle fed on grass silage barley diet
}

\author{
PEKKA HUHTANEN \\ Department of Animal Husbandry, University of Helsinki \\ SF-00710 Helsinki, Finland
}

\begin{abstract}
The effects of including yeast culture (Saccharomyces cerevisiae plus growth medium; $5 \times 10^{6}$ organisms $/ \mathrm{g}$ ) on the digestion of dietary constituents in the rumen and total digestive tract were studied in a pair of monozygote twin bulls. The animals were fitted with cannulae in the rumen and in the proximal duodenum. A diet of grass silage, barley and rapeseed meal $(445,445$ and $90 \mathrm{~g} / \mathrm{kg}$ total dry matter (DM)) was fed, with and without addition of $10 \mathrm{~g}$ per day of yeast culture (YC), in two treatment sequences.

The addition of $\mathrm{YC}$ had no effect on the mean values of rumen $\mathrm{pH}$, ammonia $\mathrm{N}$ concentration or molar proportions of volatile fatty acids. Also, the postprandial changes in rumen fermentation pattern were similar when the diet did and did not contain the YC supplement. The peak concentration of lactic acid $1 \mathrm{~h}$ after feeding tended to be higher in cattle receiving the YC diet (13.9 v $6.0 \mathrm{mmol} / \mathrm{l})$.

Apparent digestibility of organic matter $(\mathrm{OM})$ (mean 0.780 ) and the proportion of OM digestion occurring in the rumen (mean 0.603 ) were not affected by YC. Likewise, there was no effect on rumen or total digestion of cell wall carbohydrates, and the results for the degradation of hay DM in the rumen and for particle-associated carboxymethylcellulase and xylanase activities indicated that YC had no effect on the rumen environment that could affect fibre digestion. Supplemental yeast did not affect the rate of microbial $\mathrm{N}$ synthesis (28.0 and 28.6 $\mathrm{g} / \mathrm{kg} \mathrm{OM}$ apparently digested in the rumen).

The results indicate that the addition of YC to the diet is not likely to improve the efficiency of digestion and fermentation in the rumen of cattle given a diet based on grass silage and barley.
\end{abstract}

Index words: ruminant, yeast culture, digestion, rumen fermentation

\section{Introduction}

Brewer's by-products, which contain varying amounts of live and dead yeast cells (Saccharomyces cerevisiae), have been used as a supplementary protein source for dairy cows (STECKLeY et al. 1979). Recently, much data relating to the use of small amounts of live yeast cultures (YC; Saccharomyces cerevisiae) as probiotics in ruminant diets have been 
reported. Dawson and Newman (1987) observed viable yeast cells in continuous fermentors receiving yeast supplement for up to $14 \mathrm{~h}$ after feeding. On the other hand, Arambel and RUNGSYIN TUNG (1987) concluded that YC cannot maintain a productive population within the rumen ecosystem. The results of NEWBold et al. (1990) were inconclusive with regard to demonstrating yeast growth in the rumen; the decline in viable cell numbers with time after dosing was, at $0.17 / \mathrm{h}$, close to the expected rate of rumen outflow.

GÜNTHER (1989) reported addition of YC to the diet to result in proportional increases of 7.6, 16.8 and $15.2 \%$ in milk, fat and protein yield in dairy cows producing approximately $30 \mathrm{~kg} / \mathrm{d}$. WiLliams (1989) reported, using four complete mixed diets to test the effects of YC, the average milk yield to increase by $0.8 \mathrm{~kg} / \mathrm{d}$ and the fat corrected milk $(\mathrm{FCM})$ yield by $1.6 \mathrm{~kg} / \mathrm{d}$. The effects were only observed at high levels of concentrate in the diet. With diets of grass silage and barley BAX (1988) reported a mean increase of $0.4 \mathrm{~kg}$ $\mathrm{FCM} / \mathrm{d}$, the response being greater when silage and barley were given separately rather than as a complete mixed diet. In two other experiments in which cows were given total mixed rations supplemented with YC no effect on milk yield was obtained (HARRIS and LOBO 1988; QuiNONEZ et al. 1988). The effects of YC on milk composition have been varied: milk fat content has increased (Тен et al. 1987; GÜNTHER 1989), the effect has varied with the diet (Williams 1989) or else no effect has been observed (BAX 1988; HARRIS and LOBO 1988; QUINONEZ et al. 1988; HUBER et al. 1989). GÜNTHER (1989) reported a large increase in milk protein content in cows receiving YC, whilst BAX (1988) and HARRIS and LOBo (1989) found no effect, and HUBER et al. (1989) reported that YC decreased milk protein content in a large-scale trial.

The mode of action of yeast cultures has been explained by their ability to alter rumen function. Supplementation of YC has been reported to alter the rumen fermentation pattern (WiedmeIer et al. 1987; Тен et al. 1987;
HARRISON et al. 1988; MARTIN et al. 1989; Williams 1989) and to increase ruminal counts of cellulolytic bacteria (WIEDMEIER $e t$ al. 1987; Dawson and Newman 1987; HarRIson et al. 1988). Increases in the number of cellulolytic bacteria did not correspond to increases in cell wall digestion in vivo, however (HARRISON et al. 1988). The addition of YC to the diet has also changed the extent and rate of digestion in the rumen (WIEDMEIER et al. 1987; Williams 1989; Gomez-Alarcon et al. 1990). Williams (1989) suggested that the action of YC may partly be related to alleviation of a negative associative effect of concentrate supplementation. The $\mathrm{pH}$ elevation of 0.5 units with YC was related to a reduction in postprandial concentration of lactic acid in cattle given a diet of hay and barley. The results indicate that there has been large variation in response to YC supplementation both in animal performance and in rumen function. This variation may be related to the type of diet used in testing the products and also to differences in the products tested.

Most tests of the effects of YC have been carried out with diets not used in Finland. Accordingly, this experiment was designed to study the effects of YC on rumen metabolism and digestion of yeast culture (Yea-SACC'; Saccharomyces cerevisiae plus growth medium; $5 \times 10^{6}$ organisms/g) in a typical Finnish diet for cattle containing grass silage and barley. A high level of concentrate supplementation was used to monitor any effect of YC in alleviating the possible negative associative effect of a high concentrate diet.

\section{Material and methods}

\section{Animals}

The test animals were a pair of monozygote bulls of Hereford $x$ Friesian breed (initial live weight $430 \mathrm{~kg}$ ). Each had a permanent rumen cannula and a simple T-piece cannula fitted

1 Yeast culture, YEA-SACC, Alltech Biotechnology Center, 3031 Catnip Hill Pike Nicholasville, Kentucky, KY 40356. 
in the proximal duodenum. The animals were kept in metabolism cages.

\section{Diets and design}

The experiment was conducted on a switchover design. The animals received a daily allowance of $8.6 \mathrm{~kg} \mathrm{DM}$ of a diet composed on DM basis $(\mathrm{g} / \mathrm{kg})$ of grass silage 455 , barley 455 and rapeseed meal 90 , with and without a supplementation of $10 \mathrm{~g} / \mathrm{d}$ of yeast culture (YC). The animals were allocated at random to the two treatment sequences, either control diet followed by YC or the reverse. The direct-cut grass was ensiled with a formic acid based additive (AIV II; $800 \mathrm{~g}$ formic acid/ $\mathrm{kg}$ ) applied at the rate of $5 \mathrm{l} / \mathrm{t}$. Feed was offered in two equal meals at 7.00 and 19.00 hours throughout the experiment. The daily dose of YC was introduced into the rumen via the cannula in two equal portions $(5 \mathrm{~g})$ at the beginning of each feeding. Water was freely available and a commercial mineral mixture was given at the rate of $150 \mathrm{~g} / \mathrm{d}$.

\section{Experimental procedures}

Each experimental period consisted of a 14-day adaptation period followed by a 14-day period when faecal collections, rumen and duodenal samplings, nylon bag incubation and determination of the activities of polysaccharide-degrading enzymes were made.

The procedures for faecal collection, rumen and duodenal sampling and preparing the samples were as described by HuHTANEN (1988). Rumen sampling was done on two days of each period (25 and 27). Cr-mordanted straw and LiCoEDTA (UDÉn et al. 1980) were used as digesta flow markers, and purine bases (ZINN and OwENS 1986) as microbial $\mathrm{N}$ marker. A graphic alternative of FAICHNEY's (1975) double-marker method (McAllan and Smith 1983) was used to calculate the flows of dietary constituents at the duodenum. For counting the number of rumen protozoa, individual samples taken ev- ery $2 \mathrm{~h}$ were pooled to provide one composite sample per day for each animal. The samples were stored in formalin.

Triplicate samples of $3.5 \mathrm{~g}$ of hay ground to pass a $2-\mathrm{mm}$ screen were incubated in nylon bags (pore size $41 \mu \mathrm{m}$, external dimensions 120 and $60 \mathrm{~mm}$ ) for $6,12,24,48$ and $72 \mathrm{~h}$ in the rumen of each animal starting on days 16 and 23 of each period. This made 12 bags for each incubation period and treatment ( 2 days $\times 2$ periods $\times 3$ bags). The equations of McDonald (1981) were fitted to the data relating to the disappearance of DM from the bags in order to estimate degradation constants $a$ (rapidly digested soluble fraction), $b$ (degradable fraction), $c$ (rate of degradation of component $b$ ) and lag time (time elapsed before the start of the degradation).

To measure particle-associated carboxymethylcellulase (CMCase) and xylanase activities, duplicate samples of $0.6 \mathrm{~g}$ of hay were incubated in the rumen for 3, 6, 12, 24 and $48 \mathrm{~h}$. After withdrawal from the rumen the bags were washed in cold water in a house hold washing machine. The length of the washing procedure was $30 \mathrm{~min}$ consisting of 5 rinsing cycles. After washing, the bags were squeezed thoroughly. The duplicate bags were pooled before extraction of the enzymes by a procedure similar to that used by Nossal and Heppel (1966). The details of the procedure have been described by Silva et al. (1987).

Representative samples of approximately $1.0 \mathrm{~kg}$ of rumen digesta were taken on day 26 of each period. The sample was first divided into two subsamples, of which one was homogenized, and the other was strained through a cheese-cloth to obtain strained rumen fluid (SRF). Rumen particulate material (RPM) was obtained by washing the sample remaining on the cheese-cioth, using a similar procedure to that user for rumen incubated nylon bags. Duplicate samples of RPM (2 g), homogenized rumen digesta (HRD; $5 \mathrm{~g}$ ) and SRF ( $5 \mathrm{ml}$ ) were used for enzyme extraction. The DM content of RPM and HRD samples was determined at $103^{\circ} \mathrm{C}$ for $24 \mathrm{~h}$. 


\section{Chemical analysis}

Methods of chemical analysis were as described by HuHTANEN (1988). The chemical composition of the experimental feeds is presented in Table 1. The concentration of $\mathrm{D}(-), \mathrm{L}(+)$-lactic acid in rumen fluid was determined using lactic dehydrogenase in a test combination kit (Boehringer Mannheim GMDH). Protozoal counts were made using a haemacytometer after fixing with methyl green - formalin - saline (MFS) solution. The details of the determination of CMCase activity are described by GroleAu and ForsBERG (1981). Xylanase activity was assayed by the same procedure as CMCase but with $\mathrm{xy}$ lan (Sigma No. X-0376) as substrate. The samples were centrifuged at $800 \times \mathrm{g}$ for $5 \mathrm{~min}$ before the absorbance was read.

\section{Statistical analysis}

The data were analyzed by two way analysis of variance (treatment, period). For the residual sums of squares there remained 1 degree of freedom. Rumen fermentation data were analyzed by a split-plot analysis of variance (SNEDECOR and Cochran 1969).
Table 1. Chemical composition of the experimental feeds (g/kg DM).

\begin{tabular}{lccccrr}
\hline & $\begin{array}{c}\text { DM } \\
(\mathrm{g} / \mathrm{kg})\end{array}$ & Ash & N & NDF & ADF & ADL \\
\hline Grass silage $^{1}$ & 245 & 76 & 24.1 & 542 & 283 & 17 \\
Barley $_{\text {Rapeseed meal }}$ & 866 & 26 & 22.5 & 209 & 61 & 7 \\
\hline
\end{tabular}

I In silage: $\mathrm{pH} 3.75$; in DM (g/ $\mathrm{kg})$ : water-soluble carbohydrates 37 , lactic acid 67 , acetic acid 19 , butyric acid 0.4 ; in total $\mathrm{N}(\mathrm{g} / \mathrm{kg})$ : ammonia $\mathrm{N} \mathrm{35}$, soluble $\mathrm{N} 454$.

\section{Results}

\section{Rumen fermentation}

Daily values (mean, minimum, maximum and range) for rumen $\mathrm{pH}$, and for the concentrations of ammonia $\mathrm{N}$, lactic acid and volatile fatty acids (VFA) are shown in Table 2. Supplementation of the diet with YC had virtually no effect on rumen fermentation. Also, postprandial changes in rumen $\mathrm{pH}$, ammonia $\mathrm{N}$ and molar proportions of VFA were similar for the two treatments (time $\mathrm{x}$ diet interaction $\mathrm{P}>0.05)$. The postprandial increase in the molar proportion of propionate and decrease in that of acetate were slightly greater when YC was included in the diet, resulting in a larger diurnal variation in the acetate to

Table 2. Effects of yeast culture (YEA-SACC) on rumen fermentation in the cattle. The values are means of 8 sampling times except for lactic acid (4 samplings at $0-3$ after feeding).

\begin{tabular}{|c|c|c|c|c|c|c|c|c|c|}
\hline & \multicolumn{4}{|c|}{ Control } & \multicolumn{4}{|c|}{ Yeast culture } & \multirow{2}{*}{ SEM } \\
\hline & Mean & Min & $\operatorname{Max}$ & Range & Mean & Min & $\operatorname{Max}$ & Range & \\
\hline $\mathrm{pH}$ & 5.90 & 5.62 & 6.52 & 0.90 & 5.97 & 5.61 & 6.43 & 0.82 & 0.053 \\
\hline Ammonia $\mathrm{N}(\mathrm{mmol} / \mathrm{l})$ & 11.50 & 5.14 & 17.79 & 12.36 & 12.50 & 6.36 & 19.07 & 12.71 & 0.391 \\
\hline Lactic acid $(\mathrm{mmol} / \mathrm{l})$ & 1.9 & 0.1 & 6.5 & 6.4 & 5.3 & 0.1 & 13.9 & 13.8 & 0.90 \\
\hline Total VFA $(\mathrm{mmol} / \mathrm{l})$ & 135.8 & 118.3 & 152.3 & 34.0 & 134.8 & 117.0 & 155.0 & 38.0 & 2.50 \\
\hline \multicolumn{10}{|l|}{$\begin{array}{l}\text { Molar proportions } \\
\text { of VFA }(\mathrm{mmol} / \mathrm{l})\end{array}$} \\
\hline Acetic acid & 624 & 605 & 652 & 47 & 626 & 593 & 664 & 71 & 1.9 \\
\hline Propionic acid & 173 & 163 & 182 & 19 & 169 & 152 & 182 & 30 & 6.5 \\
\hline Isobutyric acid & 11.5 & 11.0 & 12.3 & 1.3 & 11.4 & 10.1 & 12.5 & 2.4 & 0.65 \\
\hline Butyric acid & 155 & 142 & 163 & 21 & 159 & 140 & 175 & 35 & 4.6 \\
\hline Isovaleric acid & 13.3 & 11.9 & 14.6 & 2.7 & 15.1 & 13.3 & 16.7 & 3.4 & 1.25 \\
\hline Valeric acid & 16.6 & 13.8 & 20.3 & 6.5 & 15.6 & 11.6 & 20.2 & 8.6 & 0.41 \\
\hline Caproic acid & 6.0 & 4.6 & 7.9 & 3.3 & 4.4 & 3.4 & 5.2 & 1.8 & 1.49 \\
\hline
\end{tabular}



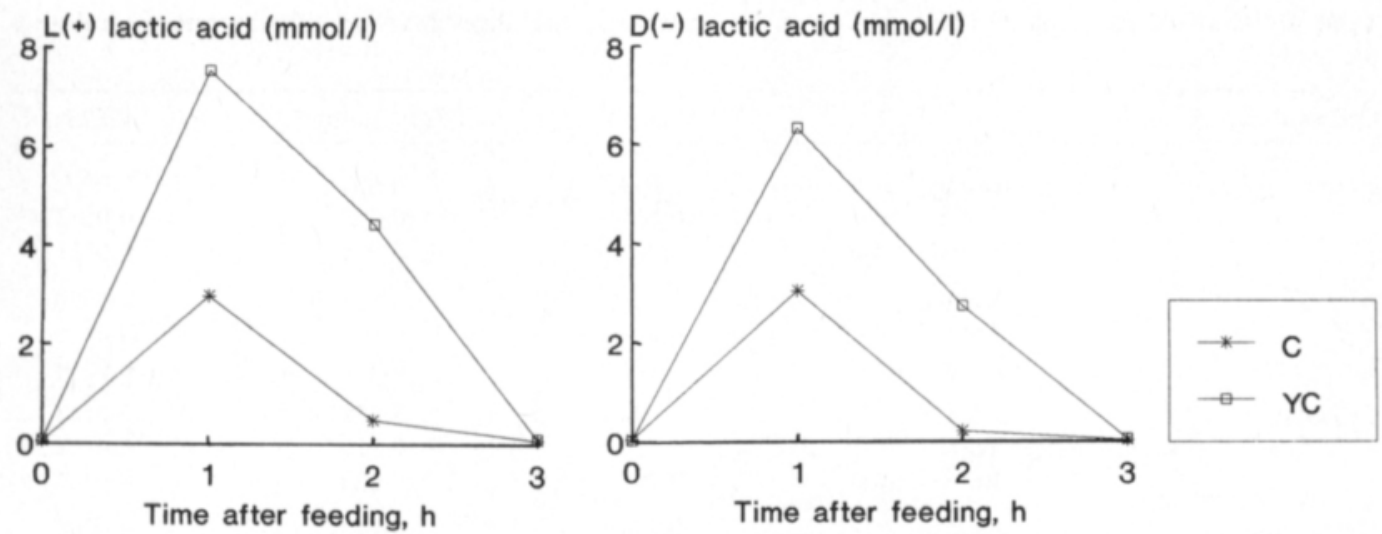

Fig. 1. The effect of yeast culture on post-prandial changes in the concentration of lactic acid in the rumen $(\mathrm{C}=$ control, YC $=$ yeast culture).

propionate ratio. The rumen acetate to propionate ratio varied by 0.67 units over the day when the cattle were given the control diet and by 1.10 units when they were given the YC supplement. The mean acetate to propionate ratio was 3.63 and 3.75 for the control and YC diets, respectively. When receiving the YC supplement the cattle tended $(\mathrm{P}<0.1)$ to have a higher ruminal concentration of lactic acid. The trend was similar for both $\mathrm{L}(+)$ and $\mathrm{D}(-)$ isomers of lactic acid (Fig. 1). The number of rumen protozoa was $10 \%$ higher when the cattle were fed the YC diet than when they were fed the control diet $\left(7.43 \times 10^{5}\right.$ vs. 6.76 $\left.\times 10^{5} ; \mathrm{SEM}=0.094\right)$.

\section{Digestion of organic matter and cell wall carbohydrates}

Organic matter (OM) intake was lower with the control diet because during the first peri- od the animal fed on this diet did not consume all its feed (Table 3). Neither rumen and total digestion of OM nor the proportion of digestion occurring in the rumen were changed by YC supplementation. Addition of YC increased the digesta flow at the duodenum by $12 \%$ (105.4 vs. $93.8 \mathrm{~kg} / \mathrm{d}$; SEM 3.15). However, the difference was only $3 \%$ when the digesta flow was calculated per $\mathrm{kg}$ DM intake.

The results for the digestion of cell wall carbohydrates are given in Table 4 . Rumen and total digestion of different cell wall constituents were virtually similar between the treatments. Addition of YC had no effect on the extent of the DM degradation of hay, but it increased the rate of degradation of from 0.0364 to $0.0475 / \mathrm{h}$ and increased the lag time of degradation (Table 5). Only after an incubation period of $48 \mathrm{~h}$ did YC supplementation show a trend towards greater disappearance of DM.

Table 3. Effects of yeast culture (YEA-SACC) on the digestion of organic matter (OM) by the cattle.

\begin{tabular}{lccccccc}
\hline Diet & \multicolumn{3}{c}{ OM $(\mathrm{kg} / 24 \mathrm{~h})$} & & \multicolumn{3}{c}{ Apparent digestibility } \\
\cline { 2 - 3 } & In feed & At duodenum & In faeces & & Rumen & Total & Rumen/total \\
\hline Control & 7.50 & 4.00 & 1.64 & & 0.469 & 0.781 & 0.600 \\
Yeast culture & 8.00 & 4.27 & 1.78 & & 0.472 & 0.780 & 0.605 \\
SEM & 0.473 & 0.287 & 0.145 & & 0.0057 & 0.0051 & 0.0033 \\
\hline
\end{tabular}


Table 4. Effects of yeast culture (YEA-SACC) on the rumen and total digestibility of cell wall carbohydrates by the cattle.

\begin{tabular}{llccc}
\hline Cell wall constituent & & Control & Yeast culture & SEM \\
\hline NDF & Rumen & 0.669 & 0.666 & 0.0009 \\
& Total & 0.686 & 0.692 & 0.0102 \\
ADF & Rumen/total & 0.971 & 0.966 & 0.0131 \\
& Rumen & 0.625 & 0.606 & 0.0091 \\
& Total & 0.644 & 0.647 & 0.0125 \\
Cellulose & Rumen/total & 0.972 & 0.937 & 0.0044 \\
& Rumen & 0.690 & 0.672 & 0.0142 \\
Hemicellulose & Total & 0.714 & 0.715 & 0.0128 \\
& Rumen/total & 0.968 & 0.939 & 0.0027 \\
& Rumen & 0.706 & 0.719 & 0.0068 \\
& Total & 0.729 & 0.726 & 0.0082 \\
& Rumen/total & 0.970 & 0.990 & 0.0203 \\
\hline
\end{tabular}

\section{Digestion of nitrogen}

The results for the digestion of nitrogenous constituents are given in Table 6. The quantities of total N, non-ammonia N (NAN) and microbial $\mathrm{N}$ entering the small intestine were slightly higher when the cattle were given the YC supplement than when they were given the control diet alone, mainly because of the difference in feed intake. Neither apparent nor true efficiency of microbial $\mathrm{N}$ synthesis in the rumen was affected by YC. Likewise, addi-

Table 5. Effects of yeast culture (YEA-SACC) on the disappearance of $\mathrm{DM}(\mathrm{mg} / \mathrm{g})$ from nylon bags incubated in the rumen of the cattle and degradation constants $(a, b$, $c$ and lag time).

\begin{tabular}{cccc}
\hline & Control & $\begin{array}{c}\text { Yeast } \\
\text { culture }\end{array}$ & SEM \\
\hline $\begin{array}{c}\text { Incubation period } \\
6 \mathrm{~h}\end{array}$ & 358 & 356 & \\
$12 \mathrm{~h}$ & 441 & 465 & 3.9 \\
$24 \mathrm{~h}$ & 578 & 587 & 17.3 \\
$48 \mathrm{~h}$ & 670 & 714 & 5.8 \\
$72 \mathrm{~h}$ & 749 & 757 & 4.8 \\
$a$ & 258 & 229 & 1 \\
$b$ & 522 & 548 & 1 \\
$c$ & 0.0364 & 0.0451 & 1 \\
Lag time (h) & 1.4 & 2.3 & 1 \\
\hline
\end{tabular}

1 Degradation constants calculated using the average values of the two animals tion of YC had no effect on the ratio of purine $\mathrm{N}$ to total $\mathrm{N}$ in isolated rumen bacteria $(0.140$ vs. 0.138$)$ and therefore the flow of microbial $\mathrm{N}$ reflected a similar pattern to purine N. YC had no effect on either apparent digestibility of $\mathrm{N}$ or faecal output of purine $\mathrm{N}$ as RNA (ribonucleic acid) equivalents.

\section{Enzyme activities}

The effect of YC on the activities of CMCase and xylanase extracted from mi-

Table 6. Effects of yeast culture (YEA-SACC) on the digestion of nitrogen $(\mathrm{N})$ by the cattle.

\begin{tabular}{|c|c|c|c|}
\hline & Control & $\begin{array}{c}\text { Yeast } \\
\text { culture }\end{array}$ & SEM \\
\hline \multicolumn{4}{|l|}{ Nitrogen (g/24 h) } \\
\hline In feed & 204.5 & 222.8 & 14.4 \\
\hline \multicolumn{4}{|l|}{ At duodenum } \\
\hline Total N & 223.0 & 231.4 & 22.7 \\
\hline Ammonia $\mathrm{N}$ & 4.5 & 4.4 & 1.8 \\
\hline Non-ammonia $\mathrm{N}$ & 218.5 & 226.9 & 20.9 \\
\hline Microbial N & 98.3 & 109.1 & 9.7 \\
\hline \multicolumn{4}{|l|}{ In Faeces } \\
\hline Total N & 55.5 & 58.9 & 3.10 \\
\hline Purine $\mathrm{N}^{1}$ & 22.2 & 22.5 & 1.56 \\
\hline \multicolumn{4}{|l|}{ Microbial N } \\
\hline$\left(\mathrm{g} / \mathrm{kg} \mathrm{OMADR}^{2}\right)$ & 28.0 & 28.6 & 1.31 \\
\hline (g/kg OMTDR $\left.{ }^{3}\right)$ & 21.5 & 21.8 & 0.77 \\
\hline
\end{tabular}





Fig. 2. The effect of yeast culture on CMCase and xylanase activities extracted from microbes associated with feed particles incubated nylon bags $(\mathrm{C}=$ control, $\mathrm{YC}=$ yeast culture $)$.

crobes associated with feed particles incubated in nylon bags for different periods of time is shown in Fig 2. The differences were not statistically significant after any period of incubation.

The activities of polysaccharide-degrading enzymes extracted from total rumen microbial population (HRD) and from a population firmly associated with feed particles were similar for the control and YC treatments (Fig. 3). The activities of CMCase in SRF were 0.57 and $0.36 \mu \mathrm{mol} / \mathrm{ml}$ per min for the control and YC treatments, and those of xylanase 0.67 and $0.55 \mu \mathrm{mol} / \mathrm{ml}$ per $\mathrm{min}$, respectively.

\section{Discussion}

In agreement with the observations of AdAMs et al. (1981) and WIEDMEIER et al. (1987), YC had no effect on rumen pH. In contrast, Williams et al. (1989) reported an increase and HARRISON et al. (1988) a decrease in rumen $\mathrm{pH}$ due to yeast supplementation. The reasons for these variable results are unclear; in the present study and in those of Harrison et al. (1988) and Williams (1989) the level of concentrate was high. The effect of $\mathrm{YC}$ on $\mathrm{pH}$ has also been variable in vitro (Dawson and Newman 1987, Martin $e t$ al. 1989). If the action of YC is related to the alleviation of the negative associative effect between forage and concentrate (WILliams 1989), it would be most likely to occur with a high concentrate diet such as used in this study. The postprandial concentration of lactic acid in the rumen was found to higher in cattle given YC, in contrast to the observations of Williams (1989) and Newbold et al. (1990). Although the difference did not reach statistical significance, the concentration of both isomers of lactic acid was consistently higher on both sampling days with YC.

The ruminal VFA pattern was not altered in the present study. In other studies the effects of YC on rumen fermentation have been variable. Harrison et al. (1988), Williams (1989), Martin et al. (1989) and Newbold et

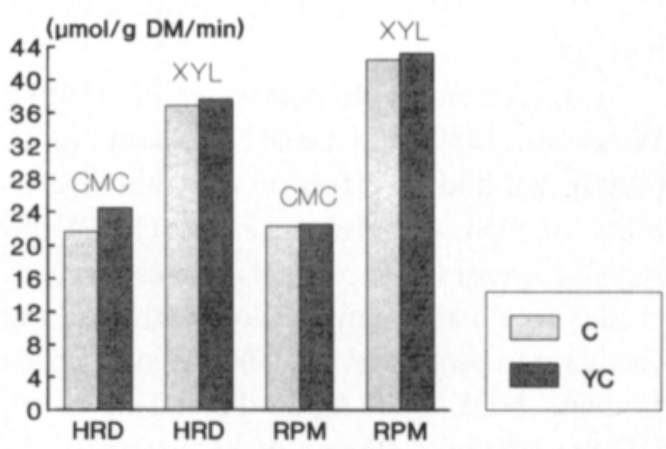

Fig. 3. The effect of yeast culture on CMCase and xylanase activities of homogenized rumen digesta (HRD) and rumen particulate material $(\mathrm{RPM})(\mathrm{C}=$ control, $\mathrm{YC}=$ yeast culture). 
al. (1990) reported that the addition of YC decreased the acetate to propionate ratio in rumen VFA. On the other hand, Williams (1987) and Tен et al. (1987) reported a higher acetate to propionate ratio in rumen VFA in animals receiving diets supplemented with YC. The variable responses to YC supplementation in milk fat content (TEH et al. 1987; GÜNTHER 1989; WILliams 1989) also indicate that the effects of YC on the rumen fermentation pattern are unpredictable. In the present study, in contrast to that of Williams (1989), no reduction in methane production in cattle fed YC would be expected on the basis of rumen fermentation stoichiometry.

The present study gave no evidence for a stabilizing effect of YC on rumen fermentation, in contrast to the observations of HARRISON et al. (1988) and Williams (1989). For most of the fermentation parameters the diurnal variation was even slightly greater when YC was included in the diet. Supplementing the silage diet with barley leads to a marked increase in the total number of rumen protozoa (ChAmberlain et al. 1985; JAAKKOLA and Huhtanen 1990), which should also stabilize rumen fermentation. UsHida et al. (1988) reported that rumen protozoa had a greater effect on cell wall digestion in animals receiving forage plus maize starch diet than in those fed on forage alone. The total number of rumen protozoa $\left(7 \times 10^{5}\right)$ was 37 and $20 \%$ higher than observed by JAAKKOLA and HuHtanen (1990) when the level of barley was 250 and $500 \mathrm{~g} / \mathrm{kg}$ total DM in grass silage based diet.

In agreement with ADAms et al. (1981), Williams (1989) and Gomez-Alarcon et al. (1990), YC had no effect on the total digestibility of OM. WIEDMEIER et al. (1987) observed increases over control in digestibility of crude protein and hemicellulose with YC, and Gomez-Alarcon et al. (1990) in that of crude protein, NDF and ADF. HARRISON et al. (1988) reported inclusion of YC in the diet to result in non-significant decreases of 5.1 and $8.4 \%$-units in the digestibility of DM and NDF. They also found that in vitro cellulose disappearance was lower for donor animals receiving YC than for controls, despite the greater counts of cellulolytic bacteria. In contrast to the observations of GOMEZ-ALARCON et al. (1990), YC had no effect on rumen digestion of $\mathrm{OM}$ or cell wall constituents in the present study. The absence of response to YC in the proportion of OM or cell wall digestion occurring in the rumen was consistent with the results for DM degradation in the rumen in nylon bags and for the activities of particle-associated polysaccharide-degrading enzymes. Faecal output of purine bases was similar for all the treatments indicating that there were no quantitative differences in the production of microbial protein in the hid-gut, and hence in the amount of carbohydrates fermented in the lower tract. The effect of YC on degradation parameters has been variable; Williams (1989) reported a shorter lag time of digestion, a slower rate and lower extent of degradation with YC, whereas in the present study the lag time was longer and the rate of digestion faster with YC. However, the different effects of YC on degradation parameters may counterbalance each other so that the total effect on rumen or total digestion of cell wall carbohydrates is likely to be small.

The absence of a difference in rumen microbial protein production between the treatments was consistent with the same mean rumen ammonia $\mathrm{N}$ concentration and similar pattern of diurnal changes. This was also in agreement with Gomez-Alarcon et al. (1990), who did not find any effect of the addition of YC on the efficiency of microbial $\mathrm{N}$ synthesis in the rumen. Although there are many factors which might influence on rumen ammonia concentration, in the present experiment any effect of YC on rumen microbial protein production should be reflected in ammonia $\mathrm{N}$ concentration. The two factors, in addition to net incorporation by rumen microbes, which may influence on rumen ammonia concentration, i.e. rumen $\mathrm{pH}$ through ammonia absorption (SIDDONS et al. 1985) and protozoal number through increased intraruminal recycling of N (COLEMAN 1975), were 
similar in the two treatments. In other studies both decreases (DAwSON and NewMAN 1987, Harrison et al. 1988, NewBold et al. 1990) and increases (ARAmbel et al. 1987; MARTIN et al. 1989) in rumen ammonia concentration have been reported.

YC had no effect on particle-associated CMCase and xylanase activities, extracted either from feed particles incubated in nylon bags or from rumen particulate matter, in agreement with the absence of an effect on either in vivo or in sacco digestion of cell wall carbohydrates. Particle-associated CMCase and xylanase activities have proved very sensitive indicators of differences in rumen environment that could affect fibre digestion (Silva et al. 1987; Huhtanen and Khalili 1989). In other studies YC has increased the number of cellulolytic bacteria in the rumen (Dawson and Newman 1987; Wiedmeier et al. 1987; Harrison et al. 1988). HARRISON et al. (1988) suggested that because cell wall digestion in vivo and cellulose digestion in vitro were reduced with YC, the activity of cellulolytic bacteria was somehow decreased.

\section{References}

Adams, D.C., Galyean, M.L., Kiesling, H.E., WalLACE, J.D. \& FINKNER, M.D. 1981. Influence of viable yeast culture, sodium bicarbonate and monensin on liquid dilution rate, rumen fermentation and feedlot performance of growing steers and digestibility in lambs. J. Anim. Sci. 53: 780-789.

Arambel, M.J. \& Rung-syin, Tung 1987. Evaluation of Saccharomyces cerevisiae growth in the rumen ecosystem. 19th Biennial Conference on Rumen Function. p. 29. Chicago, Illinois.

-, M.J., Wiedmeier, R.D. \& Walters, J.L. 1987. Influence of donor animal adaptation to added yeast culture and/or Aspergillus oryzae fermentation on in vitro fermentation. Nutr. Rep Int. 35: 433-436.

BAx, J.A. 1988. An investigation into responses of dairy cows to supplementation with yeast cultures. 2 nd International Symposium on New Techniques in Agriculture. 6.-7.9.1988, University College of Bangor, Great Britain.

Chamberlain, D.G., Thomas, P.C., Wilson, W., New.
In conclusion, the experiment reported here suggests that no improvements can be expected in the efficiency of rumen metabolism from supplementation of grass silage plus barley diet with yeast culture. This may be because of the large number of rumen protozoa with this kind of diet, which stabilize rumen fermentation. Grass silage also contains a large number of viable yeast cells, especially when ensiled with formic acid (Henderson et al. 1972). Assuming yeast cells numbering of 1 $\times 10^{5} / \mathrm{g}$ of wet silage, then in the present study the animals consumed $1.60 \times 10^{9}$ yeast cells/d. This is approximately 32 times the number of yeast cells added by feeding $10 \mathrm{~g} / \mathrm{d}$ of YC $\left(5 \times 10^{7}\right.$ yeast cells $)$. The proportion of Saccharomyces cerevisiae among silage yeasts is nevertheless generally small (WoOLFORD 1984).

Acknowledgements. The author thanks Mrs Cecilia Rosenlew-Rydbäck, Ms Leena Laitinen and Mr Juha Suomi for skilled technical assistance, Ms Ulla Kukkonen for counting rumen protozoal number and Mr Martti Tala for surgical preparation of the experimental animals. The partial support given by Alltech Biotechnology, Inc., Nicholasville, KY, USA, is gratefully acknowledged.

BOLD, C.J. \& MacDONALD, J.C. 1985. The effects of carbohydrate supplements on ruminal concentrations of ammonia in animals given diets of grass silage. J. agric. Sci., Camb. 104:331-340.

Coleman, G.S. 1975. The interrelationship between rumen ciliate protozoa and bacteria. Digestion and Metabolism in Ruminant (Ed. I.W. McDonald \& A.C.I. Warner), pp. 149-164. The University of New England Publishing Unit, Sydney.

Dawson, K.A. \& Newman, K.E. 1987. Effects of yeast culture supplements on growth and activities of rumen bacteria in continuous culture. J. Anim. Sci. 65, Suppl. 1: 452 (Abstr.).

FAICHNEY, G.J. 1975. The use of markers to partition digestion within the gastro-intestinal tract of ruminants. Digestion and Metabolism in Ruminants (Ed. I.W. McDonald \& A.C.I. Warner), pp. 277291. The University of New England Publishing Unit, Sydney.

Gomez-Alarcon, R., Dudas, C. \& Huber, J.T. 1990. In- 
fluence of cultures of Aspergillus oryzae on rumen and total tract digestibility of dietary constituents. J. Dairy Sci. 73: 703-710.

Groleau, D. \& Forsberg, C.W., 1981. Cellulolytic activity of the rumen bacterium Bacteroides sugginogenes. Can. J. Microbiol. 27: 517-530.

GUNTHER, K.D. 1989. Yeast culture's success under German dairy conditions. Biotechnology in Feed Industry: Proc. of Alltech's Fifth Annual Symposium (Ed. T.P. Lyons), pp. 39-46.

Harris, B., Jr. \& LoBo, R. 1988. Feeding yeast culture to lactating dairy cows. J. Dairy Sci., Suppl. 1: 276 (Abstr.).

Harrison, G.A., Hemken, R.W., Dawson, K.A., HarMON, R.J. \& BARKER, K.B. 1988. Influence of addition of yeast culture supplement to diets of lactating cows on ruminal fermentation and microbial populations. J. Dairy Sci. 71: 2967-2975.

Henderson, A.R., McDonald, P. \& Woolford, M.K. 1972. Chemical changes and losses during ensilage of wilted grass treated with formic acid. J. Sci. Food Agric. 23: 1079-1087.

Huber, J.T., Sullivan, J. \& Taylor, B. 1989. Effect of Yea-Sacc on milk production and related responses in a commercial dairy herd in Arizona. Biotechnology in Feed Industry: Proc. of Alltech's Fifth Annual Symposium (Ed. T.P. Lyons), pp. 35-38.

Huhtanen, P. 1988. The effects of supplementation of silage diet with barley, unmolassed sugar beet pulp and molasses on organic matter, nitrogen and fibre digestion in the rumen of cattle. Anim. Feed Sci. Technol. 20: 259-278.

- \& Khalizi, H. 1989a. Microbial polysaccharidase activities associated with rumen particulate material and feed particles incubated in nylon bags in the rumen. Asian Australasian J. Anim. Sci. 2: 400-401.

JAAKKola, S. \& Huhtanen, P. 1990. Nitrogen digestion and rumen fermentation in cattle given silage or dried grass with three levels of concentrate. Proceedings of the Ninth Silage Conference. pp. 116-117. University of Newcastle upon Tyne.

Martin, S.A., Nisbet, D.J. \& Dean, R.G. 1989. Influence of a commercial yeast supplement on the in vitro ruminal fermentation. Nutr. Rep. Int. 40: 395-403.

McAllan, A.B. \& Smith, R.H. 1983. Factors influencing the digestion of dietary carbohydrates between the mouth and duodenum. Br. J. Nutr. 50: 445-454.

McDonald, I., 1981. A revised model for the estimation of protein degradability in the rumen. J. agric. Sci., Camb. 96: 251-252.

Newbold, C.J., Williams, P.E.V., McKain, N., WalKER, A. \& W WLLACE, R.J. 1990. The effect of yeast culture on yeast numbers and fermentation in the rumen of sheep. Proc. Nutr. Soc. 49: 47A.

Nossal, N.G. \& Heppel, L.A. 1966. Release of enzymes by osmotic shock from Escherichia coli in exponen- tial phase. J. Biol. Chem. 24: 3055-3062.

Quinonez, J.A., Bush, L.J., Nalsen, I. \& Adams, G.D. 1988. Effect of yeast culture on intake and production of dairy cows fed high wheat rations. J. Dairy Sci. 71., Suppl. 1: 275 (Abstr.).

Siddons, R.C., Nolan, J.V., BeEver, D.E. \& MacRaE, J.C. 1985. Nitrogen digestion and metabolism in sheep consuming diets containing contrasting forms and levels of nitrogen. Br. J. Nutr. 54: 175-187.

Silva, A.T., Wallace, R.J. \& Ørskov, E.R. 1987. Use of particle-bound microbial activity to predict the rate and extent of fibre degradation in the rumen. $\mathrm{Br}$. $\mathrm{J}$. Nutr. 57: 407-415.

Snedecor, G.W. \& Cochran, W.C. 1967. Statistical Methods. 6th Ed. The Iowa State Univ. Press. Ames, USA.

Steckley, J.D., Grieve, D.G., Macleod, G.K. \& MoRAN, E.T., Jr. 1979. Brewer's yeast slurry. 2. A source of supplementary protein for lactating cows. J. Dairy Sci. 62: 947-953.

Teh, T.H., Sahlu, T., Escobar, E.N. \& Cutshaw, J.L. 1987. Effect of live yeast culture and sodium bicarbonate on lactating goats. J. Dairy Sci. 70, Suppl. 1: 200 (Abstr.).

Udén, P., Colucci, P.E. \& Van Soest, P.J. 1980. Investigation of chromium, cerium and cobalt as markers in digesta. Rate of passage studies. J. Sci. Food Agric. 35: $625-632$.

Ushida, K., Jouany, J.P., Kayoul., C. \& Demeyer, D.I. 1988. Effect of defaunation on fibre digestion in sheep fed $\mathrm{NH}_{3}$-treated straw based diet. The Roles of Protozoa and Fungi in Ruminant Digestion (Ed. J.V. Nolan, R.A. Leng \& D.I. Demeyer), pp. 307-308. Penambel Books, Armidale, NSW.

Wiedmeier, R.D., Arambel, M.J. \& Walters, J.L. 1987. Effect of yeast culture and Aspergillus oryzae fermentation extract on ruminal characteristics and nutrient digestibility. J. Dairy Sci. 70: 2063-2068.

Williams, P.E.V. 1987. Cellulose and lignin digestion in the rumen: How can dietary factors improve utilization. Biotechnology in the Feed Industry: Proc. of Alltech's Symposium 1987 (Ed. T.P. Lyons), pp. 97-111.

- 1989. The mode of action of yeast culture in ruminant diets: A review of the effects on rumen fermentation pattern. Biotechnology in Feed Industry: Proc. of Alltech's Fifth Annual Symposium (Ed. T.P. Lyons), pp. 65-84.

WoOLFord, M.K. 1984. The silage fermentation. Marcel Dekker Inc., New York, 350 p.

ZINN, R.A. \& OWEns, F.N. 1986. A rapid procedure for purine measurements and its use for estimation of net ruminal protein synthesis. Can. J. Anim. Sci. 66: 157-166.

Ms received December 21, 1990 


\section{SELOSTUS}

\section{Elävän hiivavalmisteen (YEA-SACC) vaikutus ravintoaineiden sulatukseen ja pötsifermentaatioon säilörehuvaltaisella ruokinnalla}

\author{
Pekka Huhtanen \\ Helsingin yliopisto, kotielaintieteen laitos, \\ 00710 Helsinki
}

Elävăn hiivavalmisteen (Saccharomyces cerevisiae + kasvatusalusta; $5 \times 10^{6}$ organismia/g) vaikutusta dieetin eri komponenttien sulatukseen ja pötsifermentaatioon tutkittiin identtisillă kaksossonneilla, joilla oli pötsi- ja ohutsuolifisteli. Ruokinta koostui säilörehusta, ohrasta ja rypsirouheesta (445, 445 ja $90 \mathrm{~g} / \mathrm{kg}$ kuiva-ainetta (ka)). Koeruokinnalla annettiin lisăksi $10 \mathrm{~g} / \mathrm{pv}$ hiivavalmistetta (YEA-SACC). Koejärjestelynă oli switchover -koe, jossa toinen sonneista oli 1 . jaksolla kontrolli- ja toinen koeruokinnalla ja 2. jaksolla päinvastoin. Koejakson pituus oli $28 \mathrm{pv}$.

Hiivalla ei ollut vaikutusta pötsinesteen keskimääräiseen $\mathrm{pH}:$ hon, ammoniakkipitoisuuteen tai haihtuvien rasvahappojen mooliosuuksiin. Myöskään ruokinnan jălkeiset muutokset ym. pötsifermentaatiota kuvaavissa parametreissả olivat samanlaisia. Ruokinnan jălkeinen $(1 \mathrm{~h})$ pötsin maitohappopitoisuus oli hiivaa saaneilla sonneilla suurempi (13.9 vs. $6.0 \mathrm{mmol} / \mathrm{l})$.

Hiivalla ei ollut vaikutusta orgaanisen aineen näen- näiseen sulavuuteen (keskimäärin 0.780) eikä pötsisulatuksen osuuteen (keskimäärin 0.603 ). Hiiva ei myöskään vaikuttanut solunseinämähiilihydraattien pötsi- tai kokonaissulavuuteen. Nailonpussimenetelmăllă määritetyn heinän kuiva-aineen pötsihajoavuuden tai partikkeleihin kiinnittyneiden mikrobien karboksimetyylisellulaasi- ja xylanaasiaktiivisuuksien perusteella arvioituna hiiva ei vaikuttanut kuidun sulatukseen pötsissă. Mikrobiproteiinin tuotantoon pötsissä hiivalla ei ollut vaikutusta.

Tămăn kokeen tulosten perusteella hiivavalmisteella ei săilörehuun perustuvalla ruokinnalla ole sellaista pötsimetaboliaa tehostavaa vaikutusta, jonka perusteella olisi odotettavissa tuotoksen lisăyksiă kasvavilla naudoilla tai lypsylehmillă. Syynă saattaa olla pötsin runsas alkueläinten mäără säilörehu-ohraruokinnalla, mikä tasoittaa pötsikäymistä. Lisäksi eläinten säilörehussa saamien hiivasolujen mäără on moninkertainen hiivavalmisteessa saatuun măăräăn verrattuna. 